\title{
A Study on Consumer Attitude Towards Fintech Services
}

\author{
Mr. Hitendra Lachhwani \\ Assistant Professor, St. Kabir Institute of Professional Studies \\ hitendra@ skips.in \\ Ms. Reenal Jain \\ PGDM Student, St. Kabir Institute of Professional Studies \\ reenal19@skips.in
}

\begin{abstract}
The research aims to determine the attitude of consumer towards FinTech and the factors that influence customers' adoption of financial technology. Descriptive Research method was used and convenience sampling was conducted to collect the data from 168 respondents from Ahmedabad. Descriptive statistics and Chi Square were used to analyze the data. The results obtained from the responses of the survey found that more number of people use digital payment services because it reduces the risk of theft, it easily reachable, and it has low cost, it saves time and it is very convenient.
\end{abstract}

\section{Keywords}

Finance, Fintech Services, Technology, Consumer Behavior, Internet Banking, Investments

\section{Introduction}

The term FinTech refers to the synergy between finance and technology to improve business operations and provide financial services. Fintech can take the form of software, services or companies. Companies can provide technologically advanced methods to improve the efficiency of financial processes by disrupting traditional methods.

Some of the most prominent FinTech applications are mobile payments, automated investment applications (robot advisors), crypto currencies, online loan companies, and crowd funding platforms.

Over the years, India has become one of the world's leading countries in adopting financial technology. The large number of digital touch points that people use every day, benefits the FinTech industry, leading to an increase in the adoption rate of FinTech services. Following are some indicators related to Indian Fintech activities:

The increase in the penetration and adoption rate of FinTech in various fields has had a positive impact on the Indian economy. The growth of digital transactions makes transparent, safe, fast and profitable mechanisms beneficial to companies, consumers and governments. 
Given the increasing attractiveness of FinTech activities in the Indian ecosystem, it is interesting to note the driving forces that led to the continued growth of the industry in the Indian context.

\section{Objectives of the study:}

- To study the behavior of consumers towards the Fintech Services.

- To identify the various factors which influence the customer to adopt Fintech services

- To establish relationship between demographics and factors influencing preference of Fintech services.

The scope of this study is limited to people using Fintech services already and the study is limited to people of Ahmedabad.

\section{Rationale of the study:}

In the digital age, financial institutions have undergone transformation to provide new services and adopt new technologies to meet customer expectations. Fintech is an innovation that uses new technologies to provide new applications, services, processes, business models and financial services. In this digitalization process, enterprises are developing rapidly; financial services. Companies have the same application advantages. The popularity of ecommerce and smart phones has promoted the entry of financial technology into a cashless economy like India. Existing research on this topic is important in understanding of the factors which will help financial institution to work upon the offering and meeting customer's expectations.

\section{Review of literature:}

\section{Convenience, Adaptability and Safety}

The study identified three main factors that affect the use of FinTech, namely convenience, adaptability and safety. It finds that customers really want to open an account conveniently within a period of time without having to contact the bank in person and determine the services provided by the bank. (Hu, Z., Ding, S., Li, S., Chen, L., \& Yang, S. 2019). The other two factors identified are adaptability and safety. The impact of these two factors is not high. Annual income also can be considered as one of the factor as adaptability is not a driving factor (Prasad, M. V. N. K. 2019)

\section{Perceived ease of use and perceived usefulness}

Previous studies have shown that the ease of use and perceived practicality of the system have found that consumers have a positive impact on the corresponding system. This situation may indicate that when people find Fintech products and services useful and easy to use; then they will improve their attitudes towards technology. A search study conducted by Chuang in Taiwan found that ease of use and practicality are closely related to consumers' attitudes towards using financial technology products. (Pejkovska, M. 2018). Fintech has some advantages, namely, easy to use, practical, convenient, and time-saving. In addition, 
research on Yemen's banking industry, ease of use and practicality of the banking system have had a positive impact on user's attitudes and intentions in using Internet banking (Baiju, M. S.2017).

\section{Perceived Risk}

Perceived risk is defined as the uncertainty that a person will encounter in their decisionmaking. In the era of data technology, perceived risks are usually interpreted as security risks or privacy risks. During this period, it is easy to obtain personal information without the owner's consent. Perceived risks have a major negative impact on individuals' attitudes towards using certain technological products or services (Arner, D. W., Barberis, J., \&Buckey, R. P. 2016). Studies have shown that the higher the perceived risk, the more unfavorable consumers' attitudes towards real technology products. It was also found that security risks have a significant impact on users' attitudes and are a key factor in the adoption of technical products. As for Martins' online banking business, the perceived risk has a great impact on consumers' attitudes towards the payment system, which in turn affects their intention to use electricity. Determining the perceived risk will determine a person's attitude towards FinTech products and services. (Das, S. 2019).

\section{Competitive Advantage}

The research shows that, competitive advantage showed a positive relationship toward intention to use a product. Competitive advantage features a positive impact towards users' attitude to internet banking in Taiwan. Similarly, Competitive advantage was closely associated with users' attitude towards mobile payment services (Ntwiga, D. B. 2018, September). The research clearly shows that the competitive advantage of the technology features a significant impact on users' attitude towards the system. However, to what extent competitive advantage has an impression on consumers' attitude towards Fintech remains uncertain (Gomber, P., Kauffman, R. J., Parker, C., \& Weber, B. W.2018).

\section{Perceived Cost}

The cost feature is the negative impact on the attitude of individuals using the system. In addition, perceived cost has a negative impact on consumer attitudes, because when it comes to product selection, cost usually becomes a priority. Similarly, the perceived cost has a negative impact on users' attitudes towards using value-added mobile services. However, cost may be a factor that potentially affects users' attitudes towards using the system. However, it is not clear to what extent the price of using financial technology products and services will affect users' attitudes (Venkatesh, V., \& Davis, F. D.2000).

\section{Linking Attitude and Intention to use Fintech}

The prior studies show that attitude is positively associated with the behavioral intention of people. This suggests that when an individual has good experience in using FinTech products and services, it'll increase his or her willingness to use it (Anagnostopoulos, I. 2018). There's a positive relationship between users' attitude and their intentions to use FinTech's products in Taiwan. Similarly, the user's attitude has a significant impact on the user's intention to use the mobile service application (MEA). In addition, he clarified that attitudes will positively 
affect consumers' intentions to use online banking. Therefore, research determines that the attitude and intention of use are closely related (Sinha, J., \&Kim, J.2012).

Most previous studies showed that attitude features a significant positive impact to the behavioral intention of individual. The behavioral intention of potential users was decided subjective norms; and therefore the behavioral intention of existing users is depend upon their behavior and attitude. A consumer's "attitude toward using" and "willingness of using" Fintech Service should have a significantly positive relationship (Varga, D. 2017). When consumers sense positive evaluations, they're going to believe that using Fintech Service may be a good experience and increase their willingness of using them. Additionally, when consumers believe that using Fintech Service may be a convenient and practical tool, they might recommend using them, the opposite consumers' attitude toward using Fintech Service are going to be affected and increased. Hence, the attitude features a positive effect relationship with behavioral intention to use (Vijai, C.2019).

\section{The Influence of Brand and Service Trust}

Moreover, trust may be a belief, expectancy, or feeling about certain items, certain antecedents will increase or maintain the degree of trust which will affect the trust of both parties on the transaction. An individual won't take any unexpected action that might end in negative outcomes or risks for the trading partners (Gulamhuseinwala, I., Bull, T., \& Lewis, S. 2015). Due to the Fintech Service are still not popular; sometimes the users of Fintech Service got to look for the services through website. When the standard and relevant functions of the merchandise are unclear, the brand can help consumers make a variety. Enterprises can cash in of the reputation of their brand value, like its stability, long history, and trustworthiness to beat a consumer's trust question. The brand and their reputation have positive effects on trust worthiness in consumers (Gomber, P., Kauffman, R. J., Parker, C., \& Weber, B. W. 2018). Through the use of new technologies, trust and experience knowledge will directly affect consumers' buying attitudes. When consumers have higher confidence in the brand and service, their attitude towards purchase will be more positive. When consumers believe that the knowledge provided by the company is honest, consumers will have a positive attitude towards the company. Hence, the definition of "brand and service trust" during this study is "the degree of influence that company reputation, website quality, and system security wear the behavioral intention of consumers to use Fintech Service" (He, M. D., Leckow, M. R. B., Haksar, M. V., Griffoli, M. T. M., Jenkinson, N., Kashima, M. M., \&Tourpe, H.2017).

\section{Research Methodology:}

The Descriptive Research method was used in order to find the attitude of consumers towards Fintech Services, a survey was conducted and questionnaire was used to know the preferences of consumers. The sampling method used was Convenience sampling method. The facts here were accumulated by investigators based on the convenience of the investigator. The facts were accumulated from a group of people who are free to participate in research. The sample size Calculated with the values (Level of confidence - 99\% (2.58), SD -0.25 and $\mathrm{E}=0.05$ ) was 166.41 i.e. 167 . The research requires checking association between 
dependent and independent variables so the statistical tool used was Chi Square.

\section{Data Analysis \& Interpretation:}

\section{Analysis of Mean Values}

a) Table:

\begin{tabular}{|l|c|c|c|c|c|}
\hline & $\begin{array}{c}\text { Strongly } \\
\text { Disagree }\end{array}$ & Disagree & Neutral & Agree & $\begin{array}{c}\text { Strongly } \\
\text { Agree }\end{array}$ \\
\hline $\begin{array}{l}\text { Security concerns prevent me from using } \\
\text { Digital Payment Services }\end{array}$ & 9 & 9 & 15 & 60 & 75 \\
\hline Using Digital Payment Service is risky & 26 & 31 & 42 & 38 & 31 \\
\hline $\begin{array}{l}\text { I fear misuse of personal information } \\
\text { when using Digital Payment Services }\end{array}$ & 7 & 9 & 25 & 46 & 81 \\
\hline $\begin{array}{l}\text { I can access this service anytime and } \\
\text { anywhere I go. }\end{array}$ & 9 & 10 & 17 & 39 & 93 \\
\hline $\begin{array}{l}\text { Digital Payment Service is the } \\
\text { cheapest way of making online } \\
\text { Payment }\end{array}$ & 26 & 31 & 42 & 38 & 31 \\
\hline $\begin{array}{l}\text { I believe Digital Payment Service } \\
\text { Provider are trustworthy }\end{array}$ & 92 & 40 & 15 & 11 & 10 \\
\hline $\begin{array}{l}\text { Integrity of the service provider has } \\
\text { important influence in choosing Digital } \\
\text { payment Services }\end{array}$ & 7 & 9 & 25 & 46 & 81 \\
\hline $\begin{array}{l}\text { Goodwill of the service provider has } \\
\text { important influence in choosing Digital } \\
\text { Payment services }\end{array}$ & 9 & 9 & 15 & 60 & 71 \\
\hline $\begin{array}{l}\text { Digital Payment service is complex and it } \\
\text { will take me a lot of time to learn how to } \\
\text { use it }\end{array}$ & 93 & 39 & 17 & 95 \\
\hline $\begin{array}{l}\text { Digital Payment is convenient and } \\
\text { the easiest to use }\end{array}$ & 9 & 8 & & 9 \\
\hline
\end{tabular}

Table 1

\section{b) Interpretations:}

According to the above table there $41 \%$ of respondent who believe that digital payment service is risky. Because of the security concern $80 \%$ of respondent do not use digital payment services. $76 \%$ them have fear of misuse of their personal information. $79 \%$ of respondent who believe that digital payment services were accessible anywhere and these 
were the cheapest way of making online payment. Digital payment service provider was not trust worthy for only $12 \%$ of respondent and goodwill and integrity were the most important factors while choosing digital payment services for $80 \%$ of respondent. $81 \%$ of people who believe that digital payment services were convenient, easiest to use and easy to learn.

Perceived Risk, Relative Advantage, Trust and convenience are the factors which can be considered important in the usage of FinTech services.

\section{Chi Square Analysis}

Moreover an attempt was made to identify the relationship between demographic factor using Chi square test and following were the results

\begin{tabular}{|c|c|c|}
\hline Hypothesis & Significant P Value & Result \\
\hline $\begin{array}{l}\text { H0: There is no significant association between Age } \\
\text { and Perceived Risk } \\
\text { Ha: There is a significant association between } \\
\text { Demographic Factors and Perceived Risk }\end{array}$ & 0.0000419481 & $\begin{array}{l}\text { Rejected H0 } \\
\text { Accepted Ha }\end{array}$ \\
\hline $\begin{array}{l}\text { H0: There is no significant association between Age } \\
\text { and Relative Advantage (Time and Cost) } \\
\text { Ha: There is a significant association between Age } \\
\text { and Relative Advantage (Time and Cost) }\end{array}$ & 0.000059007 & $\begin{array}{l}\text { Rejected H0 } \\
\text { Accepted } \mathrm{Ha}\end{array}$ \\
\hline $\begin{array}{l}\text { H0: There is no significant association between Age } \\
\text { and Trust } \\
\text { Ha: There is a significant association between Age } \\
\text { and Trust }\end{array}$ & 0.0000334516 & $\begin{array}{l}\text { Rejected H0 } \\
\text { Accepted Ha }\end{array}$ \\
\hline $\begin{array}{l}\text { H0: There is no significant association between Age } \\
\text { and Convenience } \\
\text { Ha: There is a significant association between Age } \\
\text { and Convenience }\end{array}$ & 0.0000409966 & $\begin{array}{l}\text { Rejected H0 } \\
\text { Accepted Ha }\end{array}$ \\
\hline
\end{tabular}

Table 2

Analysis:

According to the Testing Results all Null Hypothesis were rejected and all alternate Hypothesis were accepted. So this means the Age has significant association with Perceived Risk, Relative Advantage, Trust and convenience. Similarly, other demographic factors such as Education, Occupation, Monthly income were also evaluated with respect to these factors and significant association was found between Education and Trust, Occupation and Convenience. 


\section{Findings:}

Respondents were mostly female as the ratio is higher i.e. $52 \%$ and $48 \%$ Males were there. People who were between the age of 21-30 i.e. were more in size in respondents. And also 31-40 were the second highest. People who are Graduate were more in size in respondents. And also Postgraduate were second highest. People who are students were more size in respondent. And also Salaried were second highest. There were more people who have income less than 20000 rupees or we can also say that they were fewer earnings, were the highest respondents. There were majority, $39 \%$ of people who use digital payment services quarterly. There were only $16 \%$ people who frequently use digital payment services. The respondent had security and misuse concerns. Respondent had concerns over goodwill of the service provider at the same time had convenience as important factor for using the Fintech services. Demographic factors like age, education and occupation had association with all factors, trust and convenience respectively

\section{Managerial Implication:}

The results of the study will be helpful to Fintech Services provider. Once they understand the attitude and factors important for customer in usage of Fintech service, they will not only be able to serve them better and improve the business but will also be able to design their marketing strategies to attract customers.

\section{References:}

1) Anagnostopoulos, I. (2018) Fintechand reg tech: Impact on regulators and banks. Journal of Economics and Business, 100, 7-25.

2) Arner, D. W., Barberis, J., \&Buckey, R. P. (2016). FinTech, RegTech, and there conceptualization of financial regulation. Nw. J. Int'l L. \& Bus., 37,371.

3) Baiju, M. S., \&Radhakumari, C. (2017). Fintech Revolution-A Step Towards Digitization of Payments A Theoretical Framework. International Journal for Advance Research and Development, 1(2)

4) Chuang, L. M., Liu, C. C., \& Kao, H. K. (2016). The adoption of fintech service: TAM perspective. International Journal of Management and Administrative Sciences, 3(7), $1-15$.

5) Das, S. (2019). Opportunities and challenges of FinTech. keynote address at FinTech Conclave, New Delhi,25.

6) Gabor, D., \& Brooks, S. (2017). The digital revolution in financial inclusion: international development in the fintech era. New Political Economy, 22(4),423-436.

7) Gomber, P., Kauffman, R. J., Parker, C., \& Weber, B. W. (2018). Financial 
information systems and the fintech revolution.

8) Gomber, P., Kauffman, R. J., Parker, C., \& Weber, B. W. (2018). On the fintech revolution: Interpreting the forces of innovation, disruption, and transformation in financial services. Journal of Management Information Systems, 35(1),220-265.

9) Gulamhuseinwala, I., Bull, T., \& Lewis, S. (2015). FinTech is gaining traction and young, high-income users are the early adopters. Journal of Financial Perspectives,

10) He, M. D., Leckow, M. R. B., Haksar, M. V., Griffoli, M. T. M., Jenkinson, N., Kashima, M. M., ... \&Tourpe, H. (2017). Fintech and financial services: initial considerations. International Monetary Fund.

11) Huei, C. T., Cheng, L. S., Seong, L. C., Khin, A. A., \&Bin, R. L. L. (2018). Preliminary Study on consumer attitude towards FinTech products and services in Malaysia. International Journal of Engineering \& Technology, 7(2.29),166-169.

12) Hu, Z., Ding, S., Li, S., Chen, L., \& Yang, S. (2019). Adoption intention of FinTech services for bank users: An empirical examination with an extended technology acceptance model. Symmetry, 11(3), 340.

13) Mutambara, E. (2019). Predicting FinTech innovation adoption in South Africa: the case of cryptocurrency. African Journal of Economic and Management Studies.

14) Ntwiga, D. B. (2018, September). Can Fintech shape the dynamics of consumer credit usage among the un (der) banked? In Proceedings of the Kenya Bankers Association 7th Banking Research Conference.

15) Pejkovska, M. (2018). Potential negative effects of Fintech on the financial services sector. Examples from the European Union, India and the United States of America.

16) Prasad, M. V. N. K. (2019). Financial Inclusion: Emerging Role of FinTech and an Evolving Ecosystem, 85.

17) Sinha, J., \&Kim, J. (2012). Factors affecting Indian consumers' online buying behavior. Innovative marketing, 8(2),46-57.

18) Varga, D. (2017). Fintech, the new era of financial services. VezetéstudominyBudapest Management Review, 48(11),22-32.

19) Venkatesh, V., \& Davis, F. D. (2000). A theoretical extension of the technology acceptance model: Four longitudinal field studies. Management science, 46(2),186204.

20) Vijai, C. (2019). Fintech in India-Opportunities and Challenges. SAARJ Journal on Banking \& Insurance Research (SJBIR) Vol, 8 